\title{
GSTA1 wt Allele
}

National Cancer Institute

\section{Source}

National Cancer Institute. GSTA1 wt Allele. NCI Thesaurus. Code C104975.

Human GSTA1 wild-type allele is located in the vicinity of $6 p 12.2$ and is approximately 13

$\mathrm{kb}$ in length. This allele, which encodes glutathione S-transferase A1, plays a role in the metabolism of glutathione. 